\title{
Influence of calcination process on the formation of selected air pollutants
}

\author{
Jacek Wydrych $^{1 *}$, Bolesław Dobrowolski ${ }^{1}$, Grzegorz Borsuk ${ }^{1 *}$, Stawomir Pochwała ${ }^{1}$ \\ ${ }^{1}$ Opole University of Technology, Mikolajczyka 5, Opole, Poland
}

\begin{abstract}
The subject of the study is to analyze the phenomena of thermal flow in the precalcinator chamber of the exchanger's furnace tower including the combustion of coal dust and decarbonisation of raw lime powder. During the research were provided development of a mathematical model of particulate solid fuels combustion, calcining the raw material, $\mathrm{NO}_{\mathrm{x}}$ and $\mathrm{CO}_{\mathrm{x}}$ formation. Moreover conducting the number for the current and the upgraded design of the precalcinator and analysis of the results. In this study, a mathematical model based on Euler's method to describe the motion of the gas phase and the Lagrange method to describe the motion of particles [1-4]. In the calculations there were assumed fractional particles raw material and fuel, and the following processes: flow of exhaust gases from the rotary kiln through the precalcinator chamber, heat exchange between the particles of raw material and exhaust gases, the additional fuel combustion in the precalcinator, the process of raw material calcination, transformation of gaseous substances, effect of the additional (tertiary) air delivery on the processes in the chamber.
\end{abstract}

\section{Introduction}

With certainty, cement factories to some extent have cause environmental pollution. Cement industry releases carbon dioxide into the air directly by the heating of limestone, as well as the blasting in quarries causes of dust and pollutes the air [5-7]. For this reason, the cement industry is one of the primary producers of carbon dioxide, a major greenhouse gas. Studies related to the generation of carbon dioxide and other pollutants during the decarbonisation of limestone in the precalcinator chamber [8-10]. The calculations considered several different options. In particular alternatives of modified flow system by supplying tertiary air and points location of raw material to the precalcinator chamber. Completed numerical calculations have shown that the design of the precalcinator and conditions of its operation (presence of tertiary air) affects of the heat-flow and thermochemical processes in the chamber. It was found that the increase in the concentration of NOx in the furnace precalcinator chamber in all alternatives is smaller than the emission limit regulated by law.

\section{Modeling the calcination process of clinker meal particles}

Modeling the calcination process of clinker meal is a multi-stage issue. During moving the particles of raw material through the precalcinator chamber, the five stages of the calcination process can be distinguished, which is accompanied by:
1. In the pre-heating zone, the limestone is heated from room temperature to about $800^{\circ} \mathrm{C}$ by hot gases (for example: combustion products, $\mathrm{CO}_{2}$ from the calcination process and additional air).

2. From about $800^{\circ} \mathrm{C}$, the carbon dioxide pressure resulting the dissociation of limestone is equalized with the partial pressure $\mathrm{CO}_{2}$ in the gas of the precalcinator chamber.

3. When the limestone temperature exceeds $900^{\circ} \mathrm{C}$ so the distribution temperature and the partial pressure exceeds 1 atmosphere, the dissociation process can proceed from the surface toward the particle center.

4. If the calcium carbonate contained in the molecules dissolves before the particles leave the calcination zone, the lime begins to sinter.

5. Calcium particles that may contain limestone leave the calcination zone and are cooled by the air supplied for combustion.

The reaction of thermal decomposition of calcium carbonate can be described by the following formula [11]:

$$
\begin{aligned}
& \mathrm{CaCO}_{3}+\stackrel{178 \mathrm{~kJ} / \mathrm{kg}}{\longrightarrow} \mathrm{CaO}+\mathrm{CO}_{2} \uparrow \\
& 100 \mathrm{~g} \stackrel{\ldots \ldots \ldots \ldots \ldots \ldots \ldots \ldots \ldots \ldots \ldots . . \ldots \ldots \ldots \ldots \ldots \ldots \ldots}{\longrightarrow} 56 \mathrm{~g}+44 \mathrm{~g}
\end{aligned}
$$

The shrinking core model was adopted to study the distribution of spherical limestone particles in the calcination process. At a given time step there is a centrally located core of unconverted carbonate surrounded by a calcium oxide coating with a reaction phase occurring on the surface between the core and the coating $[12,13]$. On the reaction surface, the bass balance

\footnotetext{
Corresponding author: j.wydrych@po.opole.pl
} 
for the calcining material can be written in the following form:

$$
\frac{\mathrm{dm}_{\mathrm{p}, \mathrm{L}}}{\mathrm{dt}}=-\mathrm{r}_{\mathrm{c}} \frac{\mathrm{Mw}_{\mathrm{CO}_{2}}}{\mathrm{Mw}_{\mathrm{CaCO}_{3}}}
$$

where

$$
\mathrm{r}_{\mathrm{c}}={ }^{\mathrm{r}} \mathrm{k}_{\mathrm{s}}^{\prime} \cdot \mathrm{e}^{-\mathrm{E}_{2} / \mathrm{RT}_{\mathrm{L}}} \cdot 4 \cdot \pi \cdot \mathrm{r}_{\mathrm{p}}^{2} \cdot \mathrm{Mw}_{\mathrm{CaCO}_{3}}
$$

while mp,L, $\mathrm{MwCO}_{2}, \mathrm{Mw}_{\mathrm{CaCO} 3}$ are the mass of the reacting limestone, the atomic mass of carbon dioxide and the calcium carbonate. $r_{c}$ is the calcination coefficient of calcium carbonate and $r_{p}$ is the shrinking radius of the part of the non-calcined particle. The value ${ }^{\mathrm{r}} \mathrm{k}_{\mathrm{s}}^{\prime}$ is calculated from the formula:

$$
\begin{aligned}
& { }^{r} k_{s}^{\prime}={ }^{r} k_{s} \quad \text { for } \quad p_{\mathrm{CO}_{2}}<10^{-2} p_{e q} \\
& { }^{r} k_{s}^{\prime}={ }^{r} k_{s}\left(\frac{p_{\mathrm{CO}_{2}}-p_{e q}}{p_{e q}}\right) \\
& \text { for } \quad 10^{-2} p_{e q}<p_{\mathrm{CO}_{2}}<p_{e q}
\end{aligned}
$$

where

$$
\mathrm{p}_{\text {eq }}=1.826 \cdot 10^{7} \exp \left(-\frac{19680}{\mathrm{~T}_{\mathrm{L}}}\right)
$$

The ${ }^{\mathrm{r}} \mathrm{k}_{\mathrm{s}}$ component is the calcium carbonate calcination constant, while $\mathrm{T}_{\mathrm{L}}$ is the $\mathrm{CaCO}_{3}$ particle temperature. The presence of $\mathrm{CO}_{2}$ in gases affects the calcination process, but it is difficult to determine the effect of the partial pressure exerted by $\mathrm{CO}_{2}$ on this process [14]. The energy balance for the calcareous noncalcined core of the particle can be written as follows:

$$
\begin{aligned}
& \frac{d\left(m_{p, L} C_{p, s} T_{L}\right)}{d t}=h_{c, L} \cdot{ }^{L} A_{p} \cdot\left(T_{g}-T_{L}\right)+ \\
& \sigma \cdot \varepsilon_{L} \cdot{ }^{L} A_{p} \cdot\left(T_{g}^{4}-T_{L}^{4}\right)+C_{p, s} \cdot T_{L} \cdot \frac{d m_{p, L}}{d t}
\end{aligned}
$$

where $T_{L}$ is the particle core temperature, $\varepsilon \mathrm{L}$ is the emissivity of the particle, ${ }^{\mathrm{L}} \mathrm{A}_{\mathrm{P}}$ means the outer core of the particle [15]. Fig. 1 shows temperature and pressure distributions in the particle volume during the course of the calcination process.

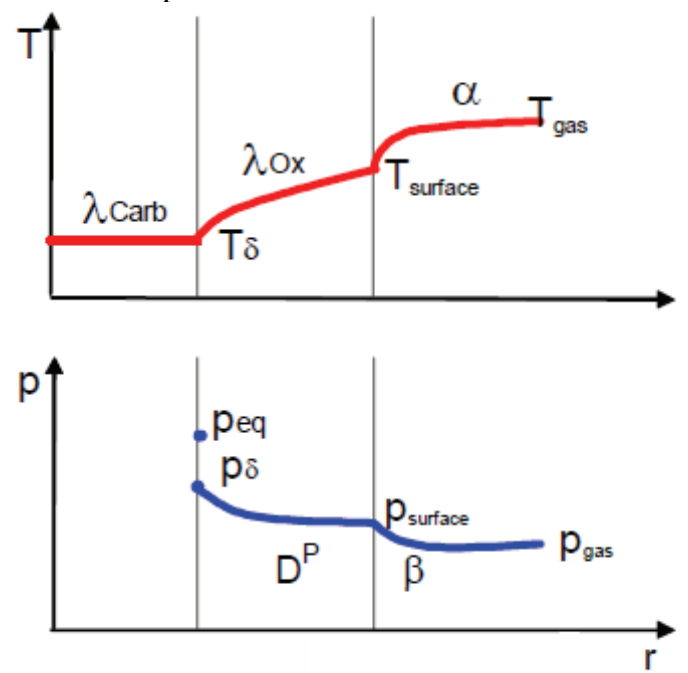

Fig. 1. Temperature and pressure distribution in the particle volume during the course of the calcination process.
The specimen comprises a dense carbonate core surrounded by a porous oxide layer. In the calcination reactor at temperature $T_{\text {gas }}$, heat is transferred by radiation and convection (symbolized by $\alpha$ ) to the solid surface at a temperature of $\mathrm{T}_{\text {surface }}$. By means of thermal conduction $\left(\lambda_{\mathrm{Ox}}\right)$ heat penetrates through the porous oxide layer to reach the reaction front, where the temperature is $\mathrm{T}_{\star}$. Fig. 2 shows the $\mathrm{CaCO}_{3}$ calcination model.

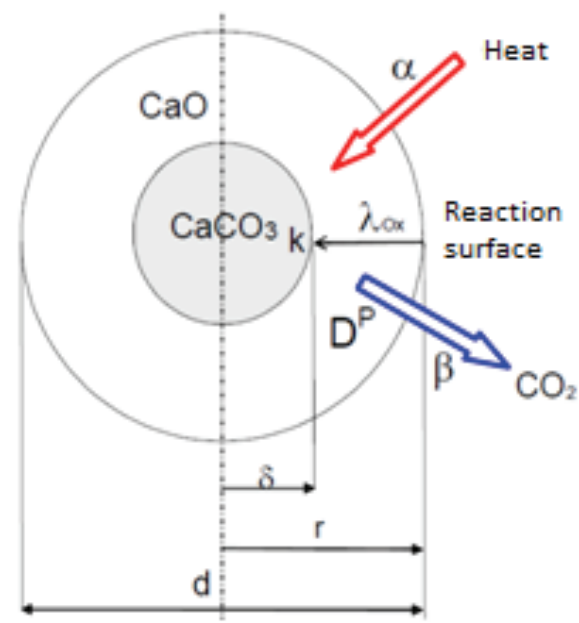

Fig. 2. $\mathrm{CaCO}_{3}$ calcination mechanism model.

As the reaction enthalpy is many times greater than the internal energy, the heat flowing further into the core is negligible during the reaction. Therefore the core temperature is only slightly lower than the front temperature. Once heat is supplied, the chemical reaction (k) then takes place, for which the driving force is the deviation of $\mathrm{CO}_{2}$ partial pressure from the equilibrium $\left(p_{e q}-p_{s}\right)$. The released $C_{2}$ diffuses $\left(D^{p}\right)$ through the porous oxide layer to the surface and finally passes by convection $(\beta)$ to the surroundings where the $\mathrm{CO}_{2}$ partial pressure $\mathrm{p}_{\text {gas }}$ exists.

\section{Modeling the NOx formation process}

The $\mathrm{NO}_{\mathrm{x}}$ forming mechanisms included in the ANSYS Fluent package allow modeling of thermal, prompt and fuel nitrogen oxides as well as their reduction during post-combustion [16]. For solving the predicted $\mathrm{NO}_{\mathrm{x}}$ emissions, the transport equations for nitric oxide concentration are solved. For thermal and prompt $\mathrm{NO}_{\mathrm{x}}$ estimation, only the transport equation for the $\mathrm{NO}$ component is required in the following form:

$$
\frac{\partial}{\partial \mathrm{t}}\left(\rho \mathrm{Y}_{\mathrm{NO}}\right)+\nabla \cdot\left(\rho \mathrm{u} \mathrm{Y}_{\mathrm{NO}}\right)=\nabla \cdot\left(\rho \mathrm{D} \nabla \mathrm{Y}_{\mathrm{NO}}\right)+\mathrm{S}_{\mathrm{NO}}
$$

where: $\mathrm{Y}_{\mathrm{NO}}$ is the mass fraction of the NO component in the gas phase, D is the effective diffusion coefficient, while $\mathrm{S}_{\mathrm{NO}}$ is the source component.

In order to estimate fuels $\mathrm{NO}_{\mathrm{x}}$, additional transport equations are required for the following gaseous components:: $\mathrm{HCN}, \mathrm{NH}_{3}$, and $\mathrm{N}_{2} \mathrm{O}$ [17]. The formation of thermal $\mathrm{NO}_{x}$ is described by a group of hightemperature chemical reactions, so-called extended Zeldovich mechanism [18]. The basic reactions 
describing the formation of such compounds from elemental nitrogen can be written as:

$$
\begin{aligned}
& \mathrm{O}+\mathrm{N}_{2} \Leftrightarrow \mathrm{N}+\mathrm{NO} \\
& \mathrm{N}+\mathrm{O}_{2} \Leftrightarrow \mathrm{O}+\mathrm{NO} \\
& \mathrm{N}+\mathrm{OH} \Leftrightarrow \mathrm{H}+\mathrm{NO}
\end{aligned}
$$

The rate of NO formation by reaction (8) can be written as follows:

$$
\begin{aligned}
& \frac{\mathrm{d}[\mathrm{NO}]}{\mathrm{dt}}=\mathrm{k}_{\mathrm{f}, 1}\left[\mathrm{O} \mathrm{N}_{2}\right]+\mathrm{k}_{\mathrm{f}, 2}\left[\mathrm{~N}[\mathrm{O}]+\mathrm{k}_{\mathrm{f}, 3}[\mathrm{~N}\rceil \mathrm{OH}\right] \\
& -\mathrm{k}_{\mathrm{r}, 1}[\mathrm{NO} \Phi \mathrm{N}]-\mathrm{k}_{\mathrm{r}, 2}\left[\mathrm{NO}[\mathrm{O}]-\mathrm{k}_{\mathrm{r}, 3}[\mathrm{NO}[\mathrm{H}]\right.
\end{aligned}
$$

where the concentration of components in parentheses is in $\mathrm{g} \mathrm{mol} / \mathrm{m}^{3}$.

Combustion of hydrocarbon fuels can result in prompt $\mathrm{NO}_{\mathrm{x}}$ formation, especially in low-temperature zones with increased fuel content, where the fuel residence time is short. Such conditions may be present on the burner surfaces, in gradual combustion or in gas turbines [19-21]. Prompt $\mathrm{NO}_{\mathrm{x}}$ outweigh the flames. The basic reactions describing the formation of such compounds can be written as:

$$
\begin{aligned}
& \mathrm{CH}+\mathrm{N}_{2} \Leftrightarrow \mathrm{HCN}+\mathrm{N} \\
& \mathrm{N}+\mathrm{O}_{2} \Leftrightarrow \mathrm{NO}+\mathrm{O} \\
& \mathrm{HCN}+\mathrm{OH} \Leftrightarrow \mathrm{CN}+\mathrm{H}_{2} \mathrm{O} \\
& \mathrm{CN}+\mathrm{O}_{2} \Leftrightarrow \mathrm{NO}+\mathrm{CO} \\
& \mathrm{CH}_{2}+\mathrm{N}_{2} \Leftrightarrow \mathrm{HCN}+\mathrm{NH}
\end{aligned}
$$

The first of the presented reactions is the most important. Research of the probability density distribution of the $\mathrm{NO}_{\mathrm{x}}$ concentration point with the $\mathrm{CH}$ concentration point shows a close correlation. This proves that the majority of $\mathrm{NO}_{\mathrm{x}}$ produced in the flame zone is the prompt $\mathrm{NO}_{\mathrm{x}}$ produced by the $\mathrm{CH}$ reaction. It is assumed that this reaction controls the rate of prompt $\mathrm{NO}_{\mathrm{x}}$ formation according to the correlation:

$$
\frac{\mathrm{d}[\mathrm{NO}]}{\mathrm{dt}}=\mathrm{k}_{0}\left[\mathrm{CH}\left\lceil\mathrm{N}_{2}\right]\right.
$$

When the fuel is in solid form, transient compounds are formed at relatively high temperatures: $\mathrm{HCN}$ and $\mathrm{NH}_{3}$. These compounds cause the formation of $\mathrm{NO}_{\mathrm{x}}$ from elemental nitrogen through nitrous oxide $\mathrm{N}_{2} \mathrm{O}$. Nitrogen enters the combustion and air supply. For certain specific conditions, i.e. oxygen-rich, high-pressure areas, this transient combustion mechanism can contribute up to $90 \%$ of all $\mathrm{NO}_{\mathrm{x}}$. The simplest form of this mechanism can be written as two reversible basic reactions:

$$
\begin{aligned}
& \mathrm{N}_{2}+\mathrm{O}+\mathrm{M} \Leftrightarrow \mathrm{N}_{2} \mathrm{O}+\mathrm{M} \\
& \mathrm{N}_{2} \mathrm{O}+\mathrm{O} \Leftrightarrow 2 \mathrm{NO}
\end{aligned}
$$

where $\mathrm{M}$ is generally the third component. Because the first reaction engages the third component, the formation of this mechanism is possible at higher pressure. Both reactions fix the oxygen so the occurrence of the mechanism is possible in the areas rich in this component. According to the laws on the reactions rate, the formation of $\mathrm{NO}_{\mathrm{x}}$ by means of transition mechanism can be written as:

$$
\frac{\mathrm{d}[\mathrm{NO}]}{\mathrm{dt}}=2\left(\mathrm{k}_{\mathrm{f}, 2}\left[\mathrm{~N}_{2} \mathrm{O}[\mathrm{O}]-\mathrm{k}_{\mathrm{r}, 2}[\mathrm{NO}]^{2}\right)\right.
$$

It is assumed that $\mathrm{N}_{2} \mathrm{O}$ is in a quasi-stationary state, which implies dependence:

$$
\left[\mathrm{N}_{2} \mathrm{O}\right]=\frac{\mathrm{k}_{\mathrm{f}, 1}\left[\mathrm{~N}_{2}[\mathrm{O}] \mathrm{M}\right]+\mathrm{k}_{\mathrm{r}, 2}[\mathrm{NO}]^{2}}{\mathrm{k}_{\mathrm{r}, 1}[\mathrm{M}]+\mathrm{k}_{\mathrm{f}, 2}[\mathrm{O}]}
$$

\section{The results of numerical calculations}

In this work mathematical model based on Euler's method to describe the motion of the gas phase and the Lagrange method to describe the motion of particles [22-26]. Numerical calculations were made on pregenerated computational meshes, as shown in Fig.3. In order to take into account the combustion process, it was necessary to add carbon fuel data as used in the precalcinator in the program. The following parameters were used:

- calorific value - $24.6 \mathrm{MJ} / \mathrm{kg}$,

- chemical composition as molar proportions: $\mathrm{C}-0.409, \mathrm{H}-0.573, \mathrm{O}-0.014, \mathrm{~N}-0.004$,

- 10 fractional RRS distributions were used for: minimum diameter $10^{-6} \mathrm{~m}$, maximum diameter $250 \cdot 10^{-6} \mathrm{~m}$, main $100 \cdot 10^{-6} \mathrm{~m}$ and separation factor 3.5.
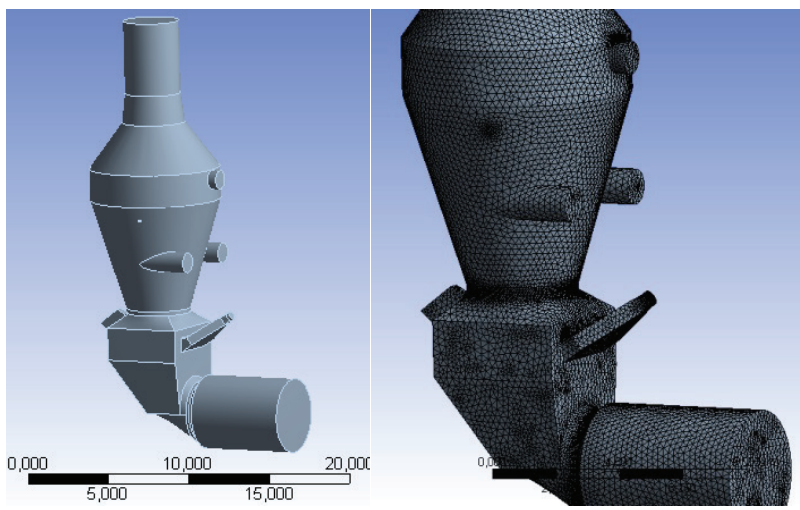

Fig. 3. The geometry of the precalcinator and numerical mesh.

\subsection{Boundary conditions}

The scheme analyzed in the calculation of the precalcinator is shown in Fig. 4.

It was assumed that a gas from the rotary kiln with weight composition $64 \% \mathrm{~N}_{2}, 29 \% \mathrm{CO}_{2}$ and $7 \% \mathrm{O}_{2}$. Individual components of the mixture were further treated separately due to the combustion process and the calcination process. Several different variants were considered in the calculation:

- W0 - Simulation for the current design of the precalcinator chamber with typical furnace operating conditions (Fig. 4).

- W0_3p - Simulation for the actual design of the precalcinator chamber at the III air intake at the intended operating conditions for the furnace (Fig. 4). 
- W0_3p_Ex - Simulation for the current design of the precalcinator chamber at the third stage of air delivery at the intended operating conditions of the furnace and when the fuel in the calciner is increased (Fig. 4).

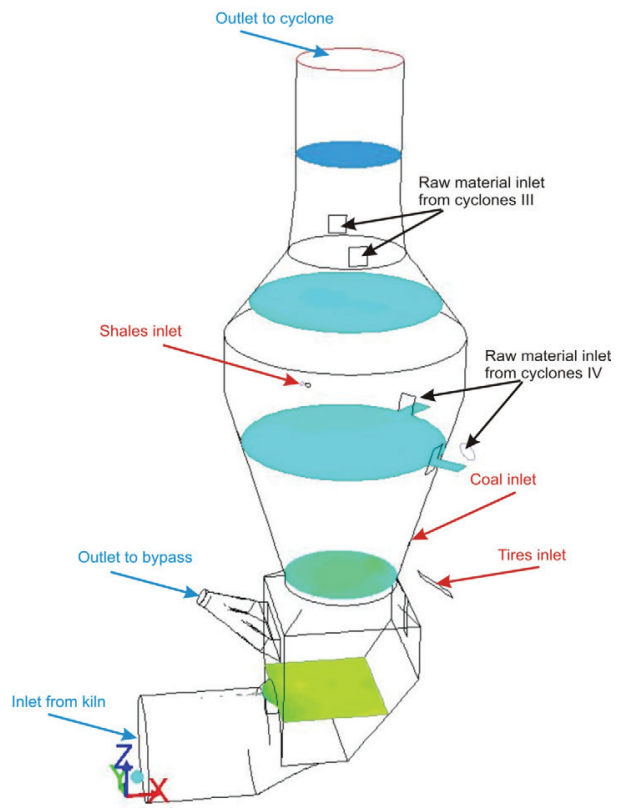

Fig. 4. Computing area.

Table 1. summarizes the accepted boundary conditions for the inlet and outlet sections. Fig. 5 shows the RRS distribution for clinker meal.

Due to the difficulty to determine actual particle size, the fractional composition of the clinker meal was scaled so as to obtain the observed separation of the meal into the rotary kiln and the heat exchangers tower. This required the use of an iterative method where the particle diameter was gradually increased. The calculations were carried out, the meal distribution was analyzed until the desired chamber/kiln ratio of $35 \% / 65 \%$ was reached.

Table 1. Boundary conditions

\begin{tabular}{|c|c|c|c|}
\hline Section & $\mathrm{v}[\mathrm{m} / \mathrm{s}]$ & $\mathrm{T}[\mathrm{K}]$ & $\mathrm{p}_{\mathrm{i}}[\mathrm{Pa}]$ \\
\hline Inlet from kiln & 15 & 1370 & -400 \\
\hline Outlet to bypas & -30 & 1100 & -400 \\
\hline $\begin{array}{l}\text { Outlet to } \\
\text { cyclones }\end{array}$ & $\begin{array}{c}\text { From the } \\
\text { balance of the } \\
\text { incoming mass }\end{array}$ & 1112 & -800 \\
\hline Coal inlet & 100 & 300 & 0 \\
\hline Shales inlet & 45 & 300 & 0 \\
\hline Tire inlet & \multicolumn{3}{|c|}{ Locked - treated as a wall } \\
\hline $\begin{array}{c}\text { Raw material } \\
\text { inlet III }\end{array}$ & \multirow{2}{*}{$\begin{array}{l}\text { From the } \\
\text { particle flow } \\
\text { rate }\end{array}$} & 1000 & 0 \\
\hline $\begin{array}{c}\text { Raw material } \\
\text { inlet IV }\end{array}$ & & 1100 & 0 \\
\hline
\end{tabular}

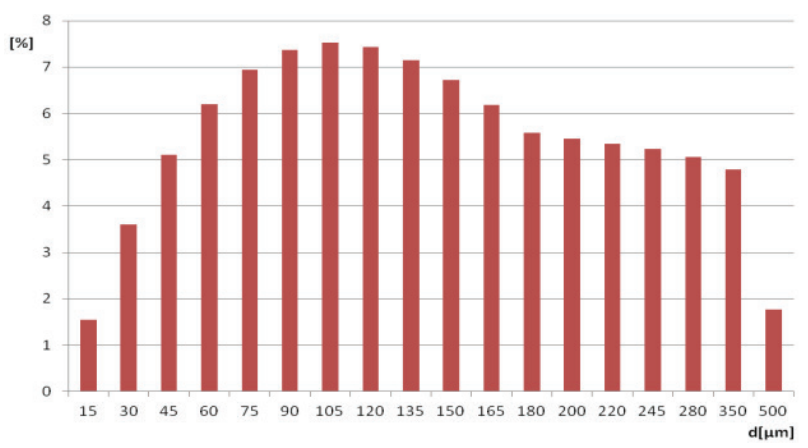

Fig. 5. Mass distribution of individual fraction obtained from the R-R-S method.

\subsection{Calculation results for gas-particle mixture flow}

Fig. 6 shows the velocity sections in the lengthwise midsection for the analyzed variants. Fig. 7 presents the temperature profile for proper conditions. Fig. 8 shows the velocity profile in cross-sections. Fig. 9 shows the particle concentration distribution in lengthwise section.
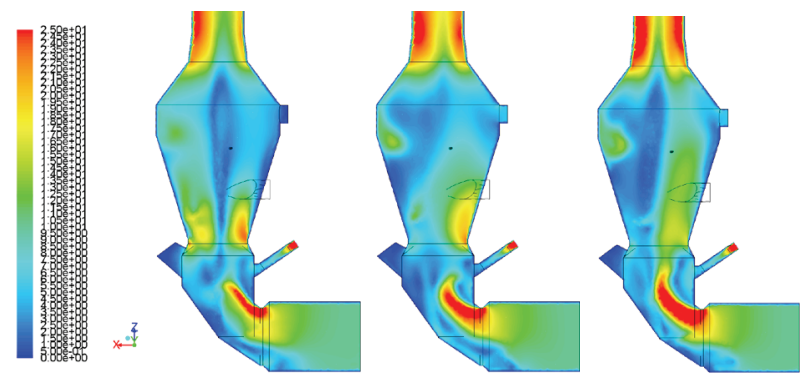

Fig. 6. Velocity profile $(\mathrm{m} / \mathrm{s})$ : variant W0, variantW0_3p, variant W0_3p_ex
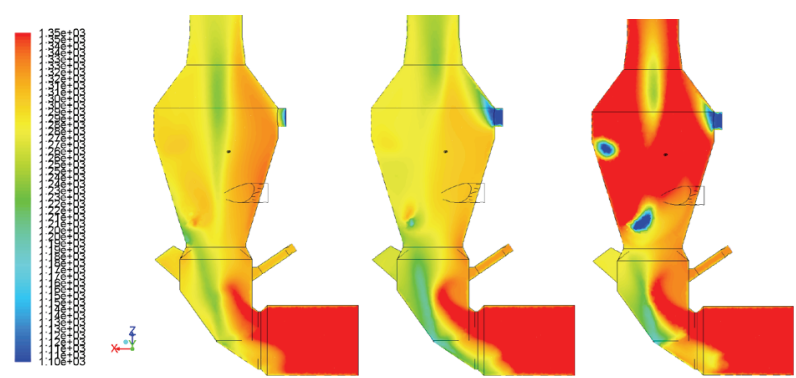

Fig. 7. Temperature profile $(\mathrm{K})$ : variant W0, variant W0_3p, variant W0_3p_ex.
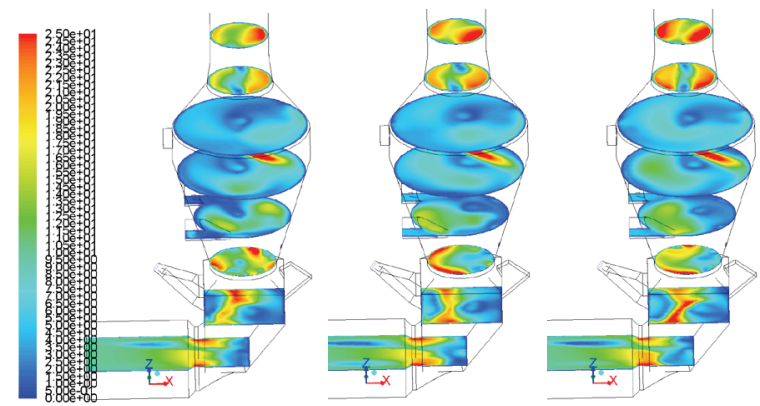

Fig. 8. Velocity profile $(\mathrm{m} / \mathrm{s})$, variant W0, variantW0_3p, variant W0_3p_ex. 

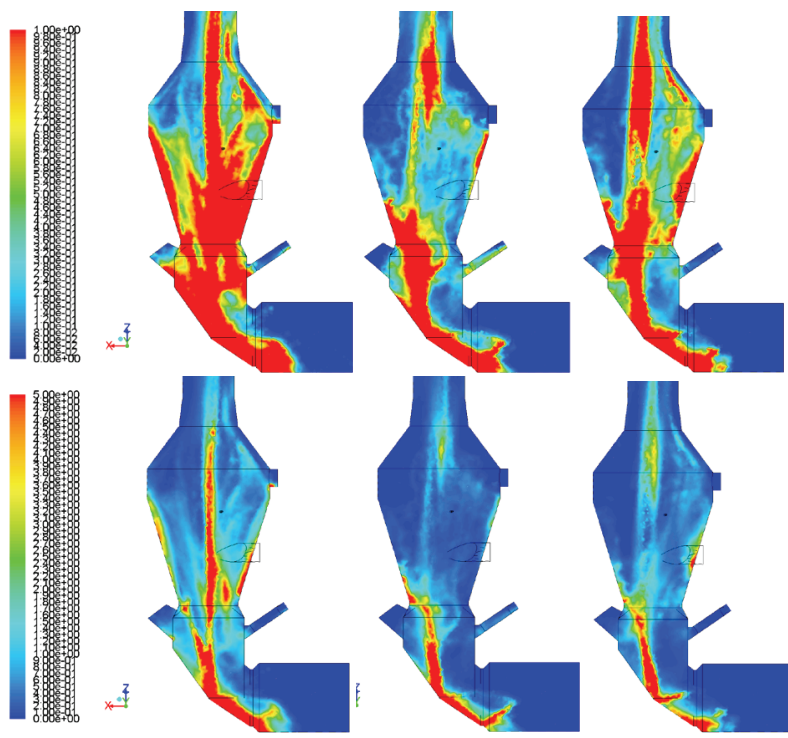

Fig. 9. Particle concentration $(\mathrm{kg} / \mathrm{m} 3)$ : variant $\mathrm{W} 0$, variant W0_3p, variant W0_3p_ex.

Fig. 10 shows the temperature profile in crosssections. Fig. 11 presents the $\mathrm{CO}_{2}$ concentration distribution in crosswise sections and $\mathrm{NO}_{\mathrm{x}}$ mass distribution in crosswise sections is shown in Fig. 12.
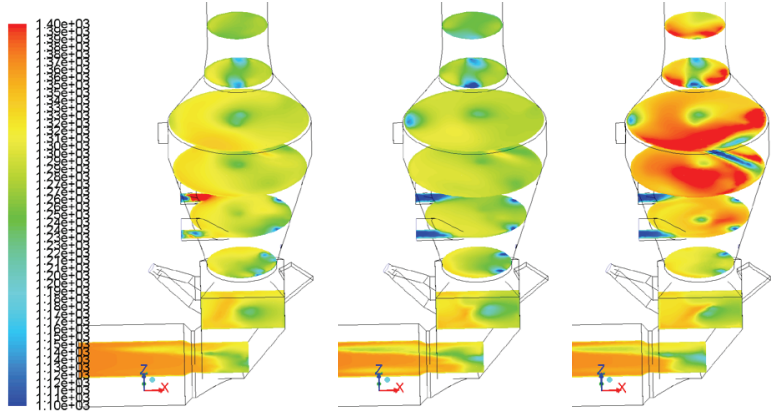

Fig. 10. Temperature profile (K), variant W0, variantW0_3p, variant W0_3p_ex.
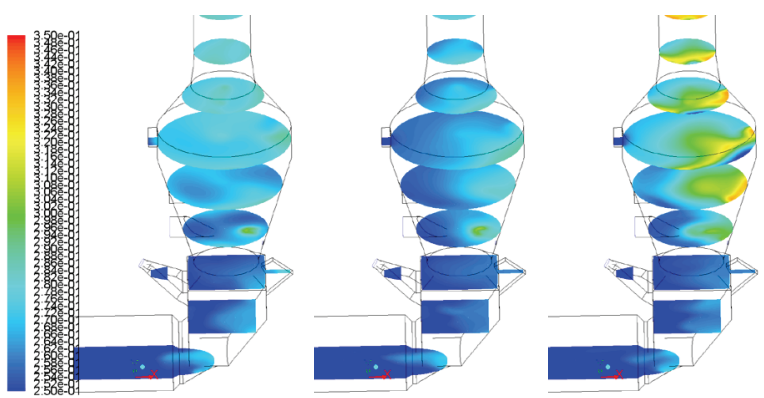

Fig. 11. $\mathrm{CO}_{2}$ concentration distribution in crosswise sections: variant W0, variant W0_3p, variant W0_3p_ex.
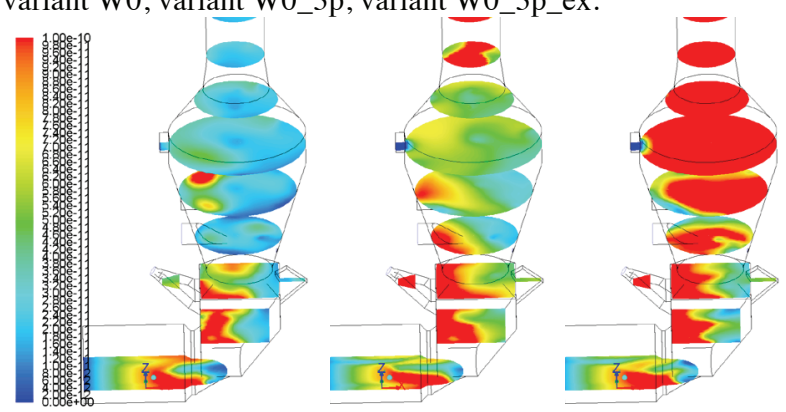

Fig. 12. $\mathrm{NO}_{\mathrm{x}}$ mass distribution in crosswise sections: variant W0, variant W0_3p, variant W0_3p_ex.
Table 2 and 3 show selected values in the outlet section of the chamber. Compiled data are average values in the cross-section of the discharge from the precalcinator. They can be useful for determining the size of derivatives and also for choosing the optimal variant. Table 4 shows the percent distribution of the meal between the inlet to the kiln and the outlet from the chamber.

Table 2. Average values in outlet section

\begin{tabular}{|l|c|c|c|}
\hline \multicolumn{1}{|c|}{ Variant } & $\begin{array}{c}\text { Temperature } \\
{[\mathrm{K}]}\end{array}$ & $\begin{array}{c}\text { Velocity } \\
{[\mathrm{m} / \mathrm{s}]}\end{array}$ & $\begin{array}{c}\text { Particle } \\
\text { concentra- } \\
\text { tion }\left[\mathrm{kg} / \mathrm{m}^{3}\right]\end{array}$ \\
\hline W0 & 1,269 & 17.23 & 0.3207 \\
\hline W0_3p & 1,254 & 19.25 & 0.2978 \\
\hline W0_3p_Ex & 1,351 & 20.92 & 0.2922 \\
\hline
\end{tabular}

Table 3. Average values in outlet section.

\begin{tabular}{|c|c|}
\hline Variant & $\begin{array}{c}\text { Pressure drop between } \\
\text { inlet and outlet [Pa] }\end{array}$ \\
\hline W0 & $515.8(-233.5282 .3)$ \\
\hline W0_3p & $345.6\left(\begin{array}{lll}-186.5 & 159.1)\end{array}\right.$ \\
\hline W0_3p ex & $365.3\left(\begin{array}{lll}-185.8 & 179.5)\end{array}\right.$ \\
\hline
\end{tabular}

Table 4. The sum of mass percentages of meal coming to both outlets of cyclones III and IV for three different flow variants.

\begin{tabular}{|c|c|c|c|c|}
\hline \multirow{2}{*}{ Variant } & \multicolumn{2}{|c|}{ From Cyclone IV } & \multicolumn{2}{c|}{ From Cyclone III } \\
\cline { 2 - 5 } & $\begin{array}{c}\text { to } \\
\text { cyclones }\end{array}$ & $\begin{array}{c}\text { to } \\
\text { kiln }\end{array}$ & $\begin{array}{c}\text { to } \\
\text { cyclones }\end{array}$ & $\begin{array}{c}\text { to } \\
\text { kiln }\end{array}$ \\
\hline W0 & $14.05 \%$ & $85.86 \%$ & $56.35 \%$ & $43.44 \%$ \\
\hline W0_3p & $5.82 \%$ & $94.16 \%$ & $55.01 \%$ & $44.30 \%$ \\
\hline W0_3p_Ex & $9.26 \%$ & $90.74 \%$ & $53.85 \%$ & $46.12 \%$ \\
\hline
\end{tabular}

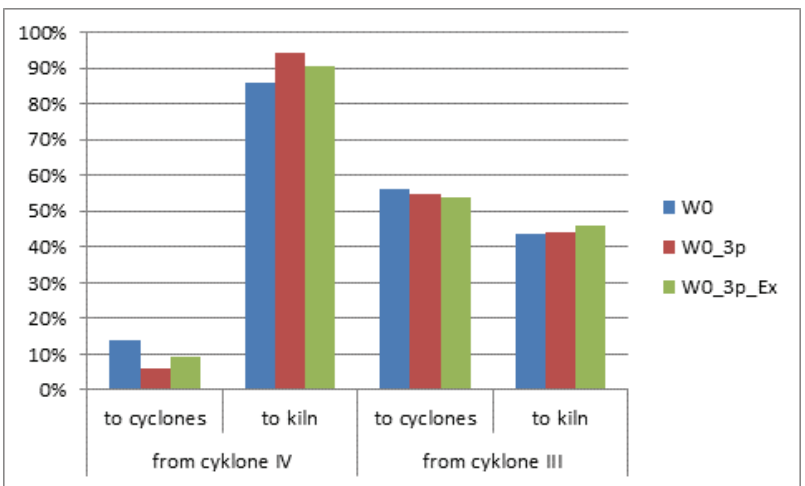

Fig. 13. Separation of meal into individual outlets for three different computational variants.

Based on Table 3 and Fig. 13, it can be concluded that, with respect to the basic variant $\mathrm{W} 0$, the variant with additional air W0_3p causes an increase in the number of particles coming from the III and IV row of the cyclones to the bottom outlet in the kiln. Table 5 and Fig. 14 show the aggregate flow rate of the scalded pulp reaching the funnel and kiln of both cyclones. The presented data show that in the case of III row cyclones the particle mass reaches the kiln approximately $2.5 \mathrm{~kg} / \mathrm{s}$. The particle mass flowing out the kiln is the largest for variant W0 $(4.5 \mathrm{~kg} / \mathrm{s})$. 
Table 5. Scaled meal mass flow rate $[\mathrm{kg} / \mathrm{s}]$ reaching the individual outlets of cyclones III and IV row for tested variants.

\begin{tabular}{|c|c|c|c|c|}
\hline \multirow{2}{*}{ Variant } & \multicolumn{2}{|c|}{ From Cyclone IV } & \multicolumn{2}{c|}{ From Cyclone III } \\
\cline { 2 - 5 } & $\begin{array}{c}\text { to } \\
\text { cyclones }\end{array}$ & $\begin{array}{c}\text { to } \\
\text { kiln }\end{array}$ & $\begin{array}{c}\text { to } \\
\text { cyclones }\end{array}$ & to kiln \\
\hline W0 & 1.7981 & 2.3425 & 4.5994 & 2.4340 \\
\hline W0_3p & 0.8565 & 1.9468 & 2.6828 & 2.8216 \\
\hline W0_Ex & 0.9007 & 2.1653 & 2.6424 & 2.4619 \\
\hline
\end{tabular}

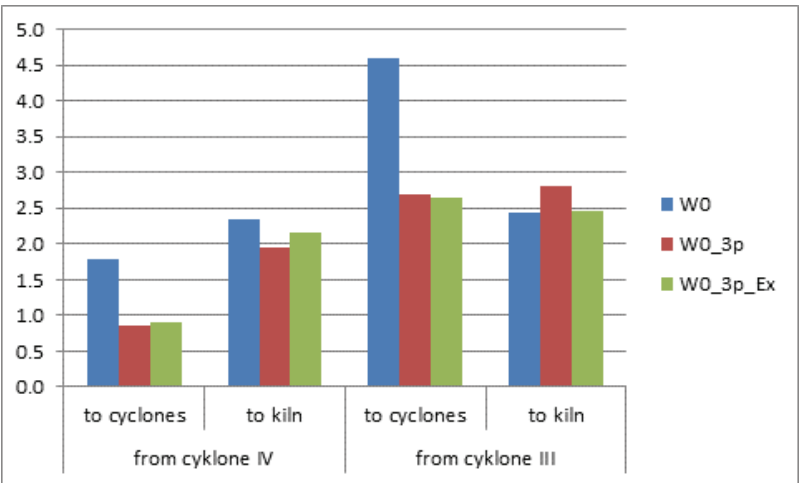

Fig. 14. Scaled meal mass flow rate $[\mathrm{kg} / \mathrm{s}]$ reaching the individual outlets.

\section{Conclusions}

Completed numerical calculations have shown that the construction of the precalcinator and its operating conditions (the presence of the tertiary air, the combusted fuel flow rate) affect the heat-flow and thermochemical processes in the chamber. It has been found that the increase of $\mathrm{NO}_{\mathrm{x}}$ concentration in the kiln heater chamber in all variants is three orders less than the permitted emission of $500 \mathrm{mg} / \mathrm{Nm}^{3}$. Lack of empirical data on $\mathrm{NO}_{\mathrm{x}}$ concentration at the outlet of the rotary kiln makes it difficult to analyze in-depth reductions in the precalcinator in detail.

It is advisable to carry out further detailed numerical studies on the optimization of the precalcinator chamber construction (burner location, air supply, a method of feeding the meal). It is also necessary to support numerical results with measurements on the object and detailed analysis of fuel and raw materials to refine the values of mathematical model coefficients.

\section{References}

1. B. Dobrowolski B., J. Wydrych, JTAM, Warszawa, 45, 25 (2007)

2. D.K. Fidaros, C,A. Baxevanou, C.D. Dritselis C.D., Vlachos N.S., Powder Technol. 171, 15 (2007)

3. Z. Hu, J. Lu, L. Huang, S. Wang, Commun. Nonlinear Sci. Numer. Simul. 11, 12 (2006)

4. L. Huang, J. Lu, F. Xia, W. Li, H. Ren, Chem. Eng. Process. 45, 10 (2006)
5. E. Worrell, L. Price, N. Martin, C. Hendriks, L. Ozawa Meida, Annu. Rev. Energy Env. 26, 27 (2001)

6. S. Zhang, E. Worrell, Crijns-Graus W., Appl. Energy,147, 22 (2015)

7. B.M. Al Smadi B, K.K. Al-Zboon, K.M. Shatnawi, Jordan J. Civ. Eng. 3, No. 3, 18 (2009)

8. K.T. Kaddatz, M.G. Rasul, A. Rahman, Procedia Eng. 56, 8 ( 2013 )

9. A. Rahman, M.G. Rasul, M.M.K. Khan, S. Sharma, Energy Procedia 61, 6 ( 2014 )

10. M.T. Javeda, N. Irfana, B.M. Gibbs, J. Environ. Manage. 83, 39 (2007)

11. P. Dai, B. González, J.S. Dennis, Chem. Eng. J. 304, $11(2016)$

12. I. Martínez, G. Grasa, R. Murillo, B. Arias, J.C. Abanades, Chem. Eng. J. 215-216, 9 (2013)

13. A. Teklay, C. Yina, L. Rosendahl, L.L. Køhler, Appl. Clay Sci. 103, 10 (2015)

14. H. Mikulcic, E. Berg, M. Vujanovic, P. Priesching, L. Perkovic, R. Tatschl, N. Duic, Chem. Eng. Sci. 69, 9 (2012)

15. A. Teklay, C. Yina, L. Rosendahl, M. Bøjer, Cem. Concr. Res. 61-62, 9 (2014)

16. ANSYS Fluent, Ansys Inc. (2016)

17. C. Schonenbeck, R. Gadiou, D. Schwartz, Fuel 83, 8 (2004)

18. Y.B. Zeldovich, G.I. Barenblatt, Combust. Flame 3 (1959)

19. S. Bhunia S., A.K. Sadhukhan, P. Gupta, Fuel Process. Technol. 158, 12 (2017)

20. W.P. Adamczyk, R.A. Bialecki, M. Ditaranto, P. Gladysz, N. Erland, L. Haugen, A. KatelbachWozniak, A. Klimanek, S. Sladek, A. Szlek, G. Wecel, Energy (to be published in 2017)

21. J. McConnell, B. Goshayeshi, J.C. Sutherland, Fuel 201, 12 (2017)

22. D.K. Fidaros, C.A. Baxevanou, C.D. Dritselis, N.S. Vlachos, Powder Technol. 171, 15 (2007)

23. W.K.H. Ariyaratne, A. Malagalage, M.C. Melaaen, L.A. Tokheim, Chem. Eng. Sci. 123, 13 (2015)

24. G. Borsuk, B. Dobrowolski, J. Wydrych, Chem. Process. Eng. 27, 12 (2006)

25. G. Borsuk, B. Dobrowolski, Chem. Process. Eng. 27, 3/2, 15 (2006)

26. R. Saidur, M.S. Hossain, M.R. Islam, H. Fayaz, H.A. Mohammed, Renew. Sustainable Energy Rev. 15, 14 (2011) 